\title{
Staphylococcus aureus Metisilin Direncinin Hızlı Saptanmasında Nitrat Redüktaz Testi: Bir Sınır Değer Duyarlılık Test Yöntemi
}

\author{
Nitrate Reductase Assay for the Rapid Detection of \\ Staphylococcus aureus Methicillin Resistance: A Breakpoint \\ Susceptibility Testing Method
}

\author{
Ahmet Yılmaz ÇOBAN ${ }^{1}$, Uğur DEMiRPEK ${ }^{2}$, Alper ÇiFTÇiं ${ }^{3}$, Bülent BOZDOĞAN ${ }^{4}$ \\ ${ }^{1}$ Ondokuz Mayıs Üniversitesi Tıp Fakültesi, Tıbbi Mikrobiyoloji Anabilim Dalı, Samsun. \\ ${ }^{1}$ Ondokuz Mayis University Faculty of Medicine, Medical Microbiology Department, Samsun, Turkey. \\ ${ }^{2}$ GATA Haydarpaşa Eğitim Hastanesi, Klinik Mikrobiyoloji Servisi, İstanbul. \\ ${ }^{2}$ GATA Haydarpasa Training Hospital, Clinical Microbiology Department, Istanbul, Turkey. \\ ${ }^{3}$ Ondokuz Mayıs Üniversitesi Veteriner Fakültesi, Mikrobiyoloji Anabilim Dalı, Samsun. \\ ${ }^{3}$ Ondokuz Mayis University Faculty of Veterinary, Microbiology Department, Samsun, Turkey. \\ ${ }^{4}$ Adnan Menderes Üniversitesi Tıp Fakültesi, Tıbbi Mikrobiyoloji Anabilim Dalı, Aydın. \\ ${ }^{4}$ Adnan Menderes University Faculty of Medicine, Medical Microbiology Department, Aydin, Turkey.
}

Geliş Tarihi (Received): 24.07.2013 • Kabul Ediliş Tarihi (Accepted): 18.11.2013

\section{ÖZET}

Metisiline dirençli Staphylococcus aureus (MRSA), toplum ve hastane kaynaklı enfeksiyonların önemli bir nedenidir. MRSA suşlarının hızlı ve doğru olarak tanımlanması, enfeksiyonun kontrolü ve bakterinin nozokomiyal yayılımını önlemek açısından büyük önem taşımaktadır. Bu çalışmada, S.aureus izolatlarında metisilin direncinin hızlı saptanması için sınır değer duyarlılık testi olarak nitrat redüktaz testi (NRT)'nin etkinliği araştııılmıştır. Çalışmaya, kültür koleksiyonumuzdan toplam 135 S.aureus klinik izolatı dahil edilmiş; suşların in vitro metisilin duyarlıı̆̆ı NRT sınır değer duyarlııı testi ve sıvı mikrodilüsyon yöntemiyle araştııılmıştır. NRT sınır değer duyarlılık testi için üç tüp kullanıımış, her bir bakteriden hazırlanan 0.5 McFarland bulanıklığındaki inokulümlerden $50^{\prime}$ şer $\mu$ l bu tüplere konulmuştur. Bu işlemden sonra tüpler $35^{\circ} \mathrm{C}^{\prime}$ de inkübe edilmiştir. Bu tüplerden biri üreme kontrolü (ilaçsız), biri test tüpü (4 mg/L sefoksitinli) ve biri liyofilize test tüpü ( $4 \mathrm{mg} / \mathrm{L}$ sefoksitinli) olarak kullanılmışı̌. Beş saatlik inkübasyon süresinin ardından taze olarak hazırlanmış ayıraçtan [2 birim \%0.2 sülfanilamid, 2 birim \%0.1 N-(1-naftil) etilendiamin dihidroklorür ve 1 birim konsantre hidroklorik asit] 500'er $\mu$ l kontrol tüpüne eklenmiştir. Kontrol tüpünde yeterli üremenin varlığını gösteren mor/menekşe bir rengin oluşması durumunda diğer iki tüpe de aynı miktarda ayıraç ilave edilmiştir. Diğer iki test tüpünde de mor/menekşe renk değişiminin gözlendiği 
durumda bakterinin sefoksitine dirençli olduğu kabul edilmiştir. Üreme kontrol tüpünde renk oluşumu gözlenirken, diğer iki test tüpünde renk oluşumunun gözlenmediği durumda ise bakterinin sefoksitine (dolayısıyla metisiline) duyarlı olduğuna karar verilmiştir. Test edilen 135 izolattan mecA pozitif olan 97'si hem sıvı mikrodilüsyon yöntemi hem de NRT sınır değer duyarlııı testiyle metisiline dirençli olarak saptanmıştır. mecA geni negatif olan 38 izolat ise her iki yöntemle de metisiline duyarlı bulunmuştur. Buna göre NRT testinin özgüllük, duyarlılık, pozitif ve negatif prediktif değerleri \%100 olarak belirlenmiştir. Sonuç olarak, tüp tabanlı NRT sınır değer duyarlılık testi birçok laboratuvar için güvenilir, tekrarlanabilir ve ucuz bir yöntemdir. Ayrıca, test sisteminin liyofilize olarak hazırlanması raf ömrünü artırmakta ve bu da laboratuvarlar için ek bir avantaj sağlamaktadır.

Anahtar sözcükler: Staphylococcus aureus; nitrat redüktaz testi; sınır değer duyarlıık testi; metisilin direnci.

\begin{abstract}
Methicillin-resistant Staphylococcus aureus (MRSA) is an important cause of hospital- and communityacquired infections. Therefore rapid and accurate detection of MRSA is essential for infection control and prevention of nosocomial spread. In this study, the efficacy of a nitrate reductase assay (NRA) as a breakpoint susceptibility testing method was evaluated for the rapid detection of methicillin resistance in S.aureus A total of 135 S.aureus clinical isolates from our collection were tested for methicillin susceptibility by NRA breakpoint susceptibility method and by broth microdilution method. For NRA breakpoint susceptibility testing three tubes including growth control tube (without drug), test tube (with $4 \mathrm{mg} / \mathrm{L}$ cefoxitin) and lyophilized test tube (with $4 \mathrm{mg} / \mathrm{L}$ cefoxitin) were used. $50 \mu \mathrm{l}$ of $0.5 \mathrm{McF}$ (arland bacterial suspension of each isolate was inoculated into the tubes. All tubes were incubated at $35^{\circ} \mathrm{C}$. After five-hour incubation, $500 \mu \mathrm{l}$ of freshly prepared reagent [ 2 units of $0.2 \%$ sulfanilamide, 2 units of $0.1 \%$ $\mathrm{N}$-(1-naphthyl) ethylenediamine dihydrochloride and 1 unit of concentrated hydrochloric acid] was added into each tube and a color change was watched for. The color changed to violet/purple, if there was bacterial growth. If the color changed to violet/purple in all three tubes, the isolate was identified as methicillin-resistant. If the color changed in growth control tube but not in the test and lyophilized tube, the isolate was identified as methicillin-susceptible. Among 135 isolates tested, 97 had mecA gene and were methicillin-resistant by both microdilution and NRA breakpoint susceptibility method. The remaining 38 clinical isolates did not have this gene and were susceptible to methicillin by both methods used. All results were concordant to the PCR which was considered as the gold standard method. Specificity, sensitivity, positive and negative predictive values were $100 \%$. NRA breakpoint susceptibility test in tubes is an inexpensive and reproducible method. This method can easily be used in many laboratories and does not require skilled personnel. In addition, test tubes are prepared by lyophilisation to provide long shelf-life which gives an important advantage.
\end{abstract}

Key words: Staphylococcus aureus; nitrate reductase assay; breakpoint susceptibility testing; methicillin resistance.

\title{
Giriş
}

Staphylococcus aureus, özellikle de metisiline dirençli S.aureus (MRSA), hem hastane hem de toplumdan kazanılmış enfeksiyonlarla ilişkili önemli bir patojendir ${ }^{1,2}$. MRSA izolatları, aminoglikozidler, makrolidler, kloramfenikol, tetrasiklin ve florokinolonlar gibi yaygın olarak kullanılan birçok antibiyotiğe dirençlidir ${ }^{3}$. MRSA'nın erken ve hızlı saptanmasının, özellikle yoğun bakım ünitelerinde bu bakterinin prevalansını azalttığı bildirilmiştir ${ }^{4}$. Metisiline duyarlı S.aureus (MSSA) ve MRSA tedavisi için uygun antibiyotik 
rejiminin erken dönemde belirlenmesi hastalar açısından çok önemlidir. Ayrıca MRSA'nın erken dönemde saptanması, gereksiz glikopeptid grubu antibiyotiklerin kullanımını önler, mortaliteyi, hastanede kalış süresini ve neden olduğu kan akımı enfeksiyonlarını, dolayısıyla da bunlara bağlı sağlık harcamalarını azaltır 5 .

Metisilin direnci mecA genine bağlıdır ve bu gen PBP2a ya da PBP2' olarak adlandırılan, PBP2'den farklı bir penisilin bağlayan proteini kodlar' ${ }^{1}$. MRSA'nın tanımlanması, bakterinin üremesinden sonra 24-48 saat gibi ek bir süre gerektirmektedir ${ }^{5}$. Önceki yıllarda S.aureus'da metisilin direncinin belirlenmesinde oksasilin kullanilırken, son yıllarda CLSI direncin belirlenmesi amacıyla mecA direncinin iyi bir indükleyicisi olan sefoksitinin kullanılmasını önermiştir ${ }^{6}$. Metisilin direncinin saptanmasında altın standart, nükleik asit probları ya da polimeraz zincir reaksiyonu (PCR) ile mecA geninin varlığının gösterilmesidir ${ }^{1}$. Günümüzde BD GeneOhm MRSA ve Cepheid Xpert gibi nazal örneklerden MRSA'nın doğrudan saptanmasını sağlayan moleküler sistemler de bulunmaktadır ${ }^{6,7}$. Bu sistemlere ek olarak S.aureus izolatlarında metisilin direncinin hızlı saptanması için bir kaç tane kolorimetrik yöntem geliştirilmiştir ${ }^{8}$. Bu yöntemlerden biri olan nitrat redüktaz testi (NRT), bazı bakterilerin biyokimyasal olarak tanımlanması ve duyarlılık testleri için kullanılan bir yöntemdir. Canlı bakterinin nitratı nitrite indirgemesi ve bunu takiben ayıracın ilave edilmesiyle renk değişiminin saptanması testin ana prensipidir ${ }^{9}$. Bu çalışmada, S.aureus izolatlarında metisilin direncinin hızlı saptanması için sınır değer duyarlılık testi temelinde NRT'nin etkinliğinin araştırılması amaçlanmıştır.

\section{GEREÇ ve YÖNTEM}

\section{Bakteri İzolatları ve Kimyasal Maddeler}

Çalışmada, kültür koleksiyonumuzda bulunan 135 S.aureus klinik izolatı ile kontrol olarak S.aureus ATCC 29213 (metisiline duyarlı) ve ATCC 43300 (metisiline dirençli) suşları test edildi. Kimyasal madde olarak çalışmada sefoksitin, sülfanilamid, N-(1-naftil) etilendiamin dihidroklorür (NED) ve potasyum nitrat (Sigma-Aldrich, Almanya) kullanıldı. Ayıraç hazırlanması için $\% 0.2^{\prime}$ lik sülfanilamid ve $\% 0.1^{\prime}$ lik NED steril distile suda çözülerek hazırlandı; kullanılıncaya kadar $4^{\circ} \mathrm{C}^{\prime}$ de saklandı. Ayıraç, 2 birim \%0.2'lik sülfanilamid ile 2 birim \%0.1'lik NED ve 1 birim konsantre hidroklorik asit $(\mathrm{HCl})$ karıştııılarak test sırasında taze olarak hazırlandı.

\section{Metisilin Direncinin Sıvı Mikrodilüsyon ve PCR Yöntemleriyle Belirlenmesi}

Metisilin direncinin saptanması amacıyla tüm izolatlar CLSI'nin önerileri doğrultusunda SıVı mikrodilüsyon yöntemiyle test edildi ${ }^{10}$. Aynı zamanda PCR yöntemiyle mecA geni varlığı araştırıldı ${ }^{11}$.

Besiyerinin hazırlanması: Tüm izolatlar katyon ayarlı ve potasyum nitrat içeren Mueller-Hinton besiyerinde (KAMHBPN) test edildi. Bu amaçla üretici firma önerilerine göre hazırlanan besiyerine $1000 \mathrm{mg} / \mathrm{L}$ olacak şekilde potasyum nitrat eklenerek sterilize edildi. Besiyeri soğuduktan sonra katyon ayarı yapıldı. 
Test tüplerinin hazırlanması: Sefoksitin duyarlılığı, sınır değer testi olarak adlandırılan yöntem ile tek bir konsantrasyonda test edildi. Bu amaçla $4 \mathrm{mg} / \mathrm{L}$ sefoksitin içeren KAMHBPN besiyerinden 1 'er $\mathrm{ml}$; üreme kontrolü için de sefoksitin içermeyen $1^{\prime} \mathrm{er} \mathrm{ml}$ KAMHBPN besiyeri tüplere dağıtıldı. Tüm tüpler kullanılıncaya kadar $4^{\circ} \mathrm{C}^{\prime}$ de saklandı.

Liyofilize test tüplerinin hazırlanması: Steril distile su içinde $4 \mathrm{mg} / \mathrm{L}$ sefoksitin içeren solüsyondan $1^{\prime} \mathrm{er} \mathrm{ml}$ tüplere dağıtılarak $-80^{\circ} \mathrm{C}$ 'de bir gece donduruldu. Dondurma işleminden sonra, tüm tüpler liyofilizasyon cihazında (MicroModulyo Freeze Dryer, Thermo Scientific, ABD) kurutuldu. Liyofilize tüpler kullanılıncaya kadar $4^{\circ} \mathrm{C}^{\prime}$ de saklandı.

Bakteri inokulümlerinin hazırlanması: Bakteri inokulümleri kanlı agarda üremiş taze bakteri kültüründen hazırlandı ve serum fizyolojik içinde 0.5 McFarland bulanıklığına ayarlandı.

NRT sınır değer testinin uygulanması: Her bir izolat için bir üreme kontrol tüpü (antibiyotiksiz), bir test tüpü (4 $\mathrm{mg} / \mathrm{L}$ sefoksitin içeren) ve bir de liyofilize test tüpü (4 $\mathrm{mg} / \mathrm{L}$ sefoksitin içeren) kullanıldı. Liyofilize test tüpü kullanılmadan önce içine $1 \mathrm{ml}$ KAMHBPN eklendi. Bunu takiben her 3 tüpe de 0.5 McFarland bulanıklığında hazırlanan bakteri süspansiyonlarından $50^{\prime}$ şer $\mu$ l eklendi ve tüpler $35^{\circ} \mathrm{C}^{\prime}$ de inkübe edildi. Beş saatlik inkübasyon süresinin ardından taze olarak hazırlanmış ayıraçtan (2 birim \%0.2 sülfanilamid, 2 birim \%0.1 NED ve 1 birim konsantre $\mathrm{HCl}$ ) 500'er $\mu$ l kontrol tüplerine eklendi. Kontrol tüpünde yeterli üremenin varlığını gösteren mor/menekşe bir rengin oluşması durumunda diğer iki tüpe de aynı miktarda ayıraç ilave edildi. Diğer iki test tüpünde de mor/menekşe renk değişiminin gözlendiği durumda bakterinin sefoksitine dirençli olduğu kabul edildi (Resim 1.1). Üreme kontrol tüpünde renk oluşumu gözlenirken, diğer iki test tüpünde renk oluşumunun gözlenmediği durumda ise bakterinin sefoksitine (dolayısıyla metisiline) duyarlı olduğuna karar verildi (Resim 1.2).

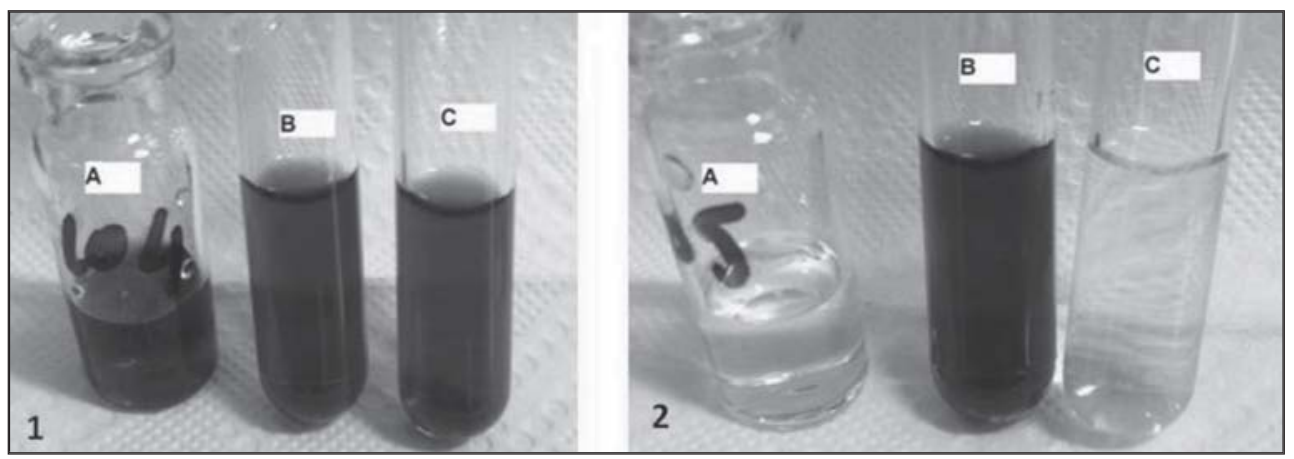

Resim 1. 1) MRSA klinik izolatı: Her üç tüpte de mor renk oluşumu bakteriyel üremeyi gösterdiğinden bakteri metisiline dirençlidir. 2) MSSA klinik izolatı: Yalnızca üreme kontrol tüpünde (B) mor renk oluşumu testin çalıştığını, diğer tüplerde renk oluşmaması bakterinin sefoksitine duyarlı olduğu için üreyemediğini yani metisiline duyarlı olduğunu göstermektedir ( $A$ : 4 mg/L sefoksitin içeren liyofilize test tüpü; B: Antibiyotik içermeyen üreme kontrol tüpü; C: 4 mg/L sefoksitin içeren test tüpü). 
Kontrol tüpünde mor/menekşe bir renk oluşması yeterli üremenin varlığını gösterdiği için kalan test tüplerine de ayıraçtan aynı miktarda eklendi. Test tüplerinin her ikisinde de mor/menekşe renk değişimi gözlendiğinde bakterinin ürediği yani sefoksitine (dolayısıyla metisiline) dirençli olduğu sonucuna varıldı. Buna karşın sadece üreme kontrol tüpünde renk oluşumu gözlenirken, test tüplerinde renk oluşumunun gözlenmemesi, bakterinin sefoksitine (dolayısıyla metisiline) duyarlı olduğunu gösterdi (Resim 1).

\section{BULGULAR}

Çalışmamızda, 135 izolatın 97'sinde PCR yöntemiyle mecA geni saptanmış; mecA pozitif olan tüm izolatlar hem sıvı mikrodilüsyon yöntemi hem de NRT sınır değer duyarlılık testiyle metisiline dirençli bulunmuştur. Bu izolatların sefoksitin Mik değeri sıvı mikrodilüsyon yöntemiyle 94'ünde > $32 \mathrm{mg} / \mathrm{L}, 2$ 'sinde $32 \mathrm{mg} / \mathrm{L}$ ve 1 'inde $16 \mathrm{mg} / \mathrm{L}$ olarak saptanmıştır. mecA geni negatif olan 38 izolat ise her iki yöntemle de metisiline duyarlı bulunmuştur. MSSA izolatlarının 31'inde sefoksitin MiK değeri $2 \mathrm{mg} / \mathrm{L}$ olarak saptanırken, 7'sinde $4 \mathrm{mg} / \mathrm{L}$ olarak belirlenmiştir.

Çalışmada NRT sınır değer testiyle elde edilen sonuçlar altın standart yöntemler olarak kabul edilen hem sıvı mikrodilüsyon yöntemi hem de PCR yöntemiyle tam uyumlu bulunmuştur. Buna göre NRT testinin özgüllük, duyarlılık, pozitif ve negatif prediktif değeri \%100 olarak belirlenmiştir.

\section{TARTIŞMA}

Toplum ya da hastane kaynaklı MRSA suşlarının hızlı ve doğru olarak saptanması, enfeksiyonun kontrolü ve bakterinin nozokomiyal yayılımını önlemek açısından önemli bir yere sahiptir ${ }^{12}$. Sıvı mikrodilüsyon yöntemiyle MiK değerinin belirlenmesi referans yöntem olarak kullanılmakla birlikte, testte elde edilen Mik değerleri, testin uygulandığı koşullara bağlı olarak değiş̧kenlik gösterebilmektedir. Günümüzde Mik değerinin saptandığı testlerin yerini büyük oranda mecA genini saptayan moleküler yöntemler almıştır. Ayrıca, lateks aglütinasyon testi ve otomatize yöntemler (Vitek/Vitek2, bioMerieux; Phoenix, Becton-Dickinson; Microscan, Dade Behring) gibi bazı hızlı testler de kullanılmaktadır ${ }^{13}$. Moleküler testler ve otomatize yöntemler pahalı olmaları, teknik deneyim gerektirmeleri ve özel ekipmanlara intiyaç duymaları nedeniyle bazı laboratuvarlar tarafından kullanılamamaktadır.

Metisilin direncinin belirlenmesinde dilüsyon yöntemleri (agar dilüsyon, sıvı mikrodilüsyon ve makrodilüsyon), E-test, agar tarama, disk difüzyon ve sınır değer (breakpoint) duyarlılık testi gibi fenotipik yöntemler bulunmaktadır. Bununla birlikte bu yöntemlerde sonuçların elde edilebilmesi için 24 saatlik bir süreye gereksinim vardır. Bu yöntemlerden sınır değer duyarlııı testi hem agarda hem de sıvı besiyerinde yapılabilmekte ve dilüsyon Mik yöntemlerine benzemektedir. Farklııı ise sınır değer duyarlılık testinin yalnızca tek bir kritik konsantrasyonda uygulanmasıdı ${ }^{13}$. Bu yöntemin avantajı, tek ilaç konsantrasyonunun kullanılmasından dolayı iş yükünün ve maliyetin azalmasıdır. 
Bu çalışmada, tüm izolatlar sefoksitin için sınır değer olan 4 mg/L konsantrasyonunda test edilmiştir. NRT sınır değer testi ucuz, uygulanması ve değerlendirilmesi kolay ve hızlı (5 saatte sonuç alınmıştır) bir yöntemdir. Bu nedenle bu yöntemle metisilin direnç sonucu, bir sonraki günü beklemeden S.aureus tanımlamasının yapıldığı aynı gün verilebilmektedir. Çoban ve arkadaşları ${ }^{8}$ vankomisin ve oksasilin duyarlılığını belirlemek için NRT'yi kullandıkları çalışmalarında, sonuçların referans yöntem olan sıvı mikrodilüsyon yöntemi ile uyumlu olduğunu bildirmiştir. Çoban ve arkadaşlarının ${ }^{9}$ bir diğer çalışmasında, S.aureus klinik izolatlarında metisilin direncinin hızı saptanması için kolorimetrik bir yöntem olan NRT MiK yönteminin etkinliği araştırılmış; elde edilen sonuçlar referans yöntem olan PCR ile karşılaştırdığında kategorik uyum \%100, temel uyum ise \%99.6 olarak saptanmıştır. Çalışmada sefoksitin Mik değerleri 5 saat gibi kısa bir sürede elde edilmiştir ${ }^{9}$. Sunulan bu çalışmada ise, NRT sınır değer testi 4 mg/L sefoksitin içeren tüplerde yapılmış; indikatör ayıraç eklendikten sonra mor/menekşe renk oluşması bakteriyel üremenin varlığını, yani metisilin direncini göstermiştir (Resim 1). Veriler referans yöntem olan PCR ile karşılaştıııldığında NRT sınır değer testinin özgüllük, duyarlılık, pozitif ve negatif prediktif değeri \%100 olarak saptanmıştır.

Son yıllarda, kromojenik besiyerleri ile metisiline dirençli stafilokokların etkin ve hızlı bir şekilde saptanabildiği rapor edilmektedir ${ }^{14}$. Merlino ve arkadaşları $^{15}$, kromojenik bir besiyerinin (CHROMagar Staph aureus, Fransa), S.aureus'un tanımlanmasında ve koagülaz-negatif stafilokoklardan (KNS) ayırt edilmesindeki performansını araştırmışlar; bu besiyerinin hastane kökenli MRSA izolatlarının tamamını doğru olarak tanımlarken, toplum kökenli MRSA izolatlarının ancak \%30'unu doğru olarak tanımladığını bildirmişlerdir. Bir sürveyans çalışmasında Morris ve arkadaşları $^{16}$ burun sürüntü örneklerinde MRSA araştırılması amacıyla ChromID MRSA (bioMerieux), Brilliance MRSA 2 Agar (Oxoid) ve Colorex MRSA (EO Laboratories) kolorimetrik besiyerlerini kullanmışlardır. Araştırıcılar, bu besiyerleriyle elde edilen test sonuçlarının inkübasyon süreleriyle ilişkili olduğunu ifade etmişler ve eğer öncelik yüksek duyarlılık ise ChromID MRSA besiyerinin; öncelik 24 saat içinde sonuç alınması ise Colores MRSA besiyerinin daha uygun olduğunu belirtmişlerdir. Ayrıca ChromID MRSA için MRSA doğrulamasının yapılmasını da önermişlerdir ${ }^{16}$. Lee ve arkadaşları $^{17}$ nazal sürüntü örneklerinden MRSA izolatlarının saptanmasında üç kolorimetrik besiyeri ve Xpert MRSA testinin etkinliğini araştırmışlar; yöntemlerin hiçbirinde duyarlılık ve özgüllük belirlenmemiş olsa da sağlık kuruluşlarında MRSA taramasında kullanılabileceğini belirtmişlerdir. Bizim çalışmamızda kullanılan kolorimetrik NRT ile S.aureus olarak tanımlanmış (özellikle hızlı testlerle) izolatlarda metisilin direncinin varlığı aynı gün içerisinde verilmektedir. Kromojenik tarama testlerinde 16-48 saat arasında sonuç alınmakla birlikte genellikle inkübasyon süresinin uzatılması testin duyarlılığını artırmaktadır.

Çoban ve arkadaşları $^{18}$ S.aureus klinik izolatlarında Quicolor ES agar (Salubris Inc.) kullanarak kolorimetrik disk difüzyon yöntemiyle metisilin direncinin varlığını 4-9 saat arasında tanımlamışlardır. Bu yöntemde, besiyerinde gözlenen renk değişimine göre 
üremenin varlı̆̆ı belirlenip diskin etrafında gözlenen renk değişimi ölçülerek değerlendirme yapılmaktadır; ancak 4 ile 9 saat arasındaki sürelerde besiyerinin sürekli kontrolünün yapılması gerekmektedir. Bizim çalışmamızda kullanılan NRT testinde ise ayıraç eklendikten sonra saniyeler içinde renk değişimi gözlenmektedir. Çalışmamızda ayrıca raf ömrünü uzatmak için $4 \mathrm{mg} / \mathrm{L}$ sefoksitin içeren liyofilize tüpler hazırlanıp test edilmiştir. Liyofilize ve taze hazırlanmış test tüpleri eş zamanlı olarak test edildiğinde, elde edilen sonuçların karşılaştıııması, her iki tüpte yapılan testlerin sonuçlarının da aynı olduğunu ortaya koymuştur. Bu sonuçlar, liyofilize olarak hazırlanan antibiyotikli tüplerin raf ömrü uzatılarak birçok laboratuvar tarafından kolaylıkla kullanılabileceğini göstermektedir.

Günümüzde S.aureus'un tanımlanmasında, tüp ve lam koagülaz testleri, lateks aglütinasyon testi, DNaz ve ısıya dayanıklı nükleaz testleri, çok sayıda moleküler testler ve ayrıca hızlı ticari testler (örn. BBL coagulase Plasma, Rabbit ve Oxoid Staphylase) kullanılmaktadır ${ }^{9,13}$. S.aureus'un tanısını takiben NRT sınır değer testiyle 5 saat gibi kısa bir sürede olmak üzere, aynı gün metisilin direncinin de saptanması ve bildirilmesi, klinisyenin erken ve uygun antibiyotik tedavisine başlamasına olanak sağlayacaktır. Bu yöntem devlet hastaneleri, üniversite eğitim ve araştırma hastaneleri ve özel klinik mikrobiyoloji laboratuvarları tarafından sağlık hizmeti ve araştırma amacı için kullanılabilecek bir yöntemdir. Sonuç olarak, tüp tabanlı NRT sınır değer testi birçok laboratuvar için güvenli, tekrarlanabilir ve ucuz bir yöntem olup, test sisteminin liyofilize olarak hazırlanarak raf ömrünün de uzatılması ek bir avantaj sağlayacaktır.

\section{KAYNAKLAR}

1. Monson LS. Staphylococci, pp: 316-9. In: Mahon CR, Lehman DC, Manuselis G (eds), Textbook of Diagnostic Microbiology. 2011, $4^{\text {th }}$ ed. Saunders Elsevier, Missouri.

2. von Eiff C, Maas D, Sander G, Friedrich AW, Peters G, Becker K. Microbiological evaluation of a new growthbased approach for rapid detection of methicillin-resistant Staphylococcus aureus. J Antimicrob Chemother 2008; 61(6): 1277-80.

3. Al-Talib H, Yean CY, Al-khateeb A, et al. Comparative evaluation of five culture media with triplex PCR assay for detection of methicillin-resistant Staphylococcus aureus. Curr Microbiol 2010; 61(1): 1-6.

4. Rossney AS, Herra CM, Brennan GI, Morgan PM, O'Connell B. Evaluation of the Xpert methicillin-resistant Staphylococcus aureus (MRSA) assay using the GeneXpert real-time PCR platform for rapid detection of MRSA from screening specimens. J Clin Microbiol 2008; 46(10): 3285-90.

5. Gröbner S, Dion M, Plante M, Kempf VA. Evaluation of the BD GeneOhm StaphSR assay for detection of methicillin-resistant and methicillin-susceptible Staphylococcus aureus isolates from spiked positive blood culture bottles. J Clin Microbiol 2009; 47(6): 1689-94.

6. Clinical and Laboratory Standards Institute. Performance standards for antimicrobial susceptibility testing. Twenty-third Informational Supplement. Document M100-S23, 2013. CLSI, Wayne PA.

7. Wolk DM, Struelens MJ, Pancholi P, et al. Rapid detection of Staphylococcus aureus and methicillin-resistant S.aureus (MRSA) in wound specimens and blood cultures: multicenter preclinical evaluation of the Cepheid Xpert MRSA/SA skin and soft tissue and blood culture assays. J Clin Microbiol 2009; 47(3): 823-6.

8. Patel PA, Ledeboer NA, Ginocchio CC, et al. Performance of the BD GeneOhm MRSA achromopeptidase assay for real-time PCR detection of methicillin-resistant Staphylococcus aureus in nasal specimens. J Clin Microbiol 2011; 49(6): 2266-8. 
9. Coban AY, Bozdogan B, Cihan CC, et al. Two new colorimetric methods for early detection of vancomycin and oxacillin resistance in Staphylococcus aureus. J Clin Microbiol 2006; 44(2): 580-2.

10. Coban AY. Rapid determination of methicillin resistance among Staphylococcus aureus clinical isolates by colorimetric methods. J Clin Microbiol 2012; 50(7): 2191-3.

11. Clinical and Laboratory Standards Institute. Methods for dilution antimicrobial susceptibility tests for bacteria that grow aerobically. $6^{\text {th }}$ ed. Approved Standard M7-A6, 2003. CLSI, Wayne, PA.

12. McClure JA, Conly JM, Lau V, et al. Novel multiplex PCR assay for detection of the staphylococcal virulence marker Panton-Valentine leukocidin genes and simultaneous discrimination of methicillin-susceptible from -resistant staphylococci. J Clin Microbiol 2006; 44(3): 1141-4.

13. Cesur S, Yildiz E, Irmak H, et al. Evaluation of oxacillin resistance screening agar and chromogenic MRSA agar media for the detection of methicillin resistance in Staphylococcus aureus clinical isolates. Mikrobiyol Bul 2010; 44(2): 279-84.

14. Brown DF, Edwards DI, Hawkey PM, et al. Guidelines for the laboratory diagnosis and susceptibility testing of methicillin-resistant Staphylococcus aureus (MRSA). J Antimicrob Chemother 2005; 56(6): 1000-18.

15. Merlino J, Leroi M, Bradbury R, Veal D, Harbour C. New chromogenic identification and detection of Staphylococcus aureus and methicillin-resistant S.aureus. J Clin Microbiol 2000; 38(6):2378-80.

16. Lee S, Park YJ, Park KG, et al. Comparative evaluation of three chromogenic media combined with broth enrichment and the real-time PCR-based Xpert MRSA assay for screening of methicillin-resistant Staphylococcus aureus in nasal swabs. Ann Lab Med 2013; 33(4): 255-60.

17. Morris K, Wilson C, Wilcox MH. Evaluation of chromogenic methicillin-resistant Staphylococcus aureus media: sensitivity versus turnaround time. J Hosp Infect 2012; 81(1): 20-4.

18. Coban AY, Demirpek U, Yildirim T, Cayci YT, Kocagoz T, Durupinar B. Rapid detection of methicillin resistance in Staphylococcus aureus isolates; evaluation of colorimetric Quicolor ES agar and determination of breakpoint inhibition zone diameters of cefoxitin. World J Microbiol Biotechnol 2011; 27(8): 1901-4. 